\title{
Obituaries
}

Obituaries should be submitted by email to Jadene Doak at jadene.doak@springernature.com

All submitted obituaries should be 400 words maximum in length (apart from obituaries for past presidents of the BDA where the length should be 800 words).

Content of the obituary is down to the individual author, and the approval of the family should be given for the obituary prior to submission to the BDJ.

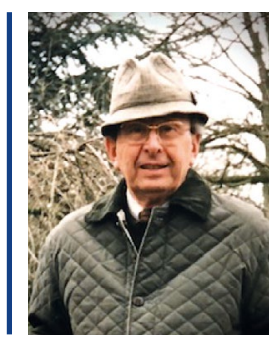

Adam Lenko

1924-2020

Adam was born in Kolomyia, at that time a town in south-eastern Poland. In this area of rivers and woodland he enjoyed outdoor pursuits such as scouting trips, camping and fishing. In 1939, this region was invaded by the Red Army and Adam was taken along with his mother and sister to a remote area of Siberia. He used this long and gruelling train journey to learn bridge and chess.

Several harsh years followed including deliverance from a fierce blizzard by his trusty ox finding home after a milk delivery. When the Soviets joined the allies Adam was allowed to enlist in the Polish Air Force and embarked on an epic journey to reach Britain. Crossing the Caspian Sea, passing through Iran and Iraq, and sailing to Bombay, Cape Town and Freetown all preceded his arrival in Glasgow. Adam overcame severe bouts of frostbite, malaria and typhus en route. His happiest moment was literally walking into his sister on a Lebanese beach after four months of separation.

After training at various RAF bases Adam qualified as a navigator for a Polish bomber squadron. He flew in the famed de Havilland Mosquito and his missions after the war included delivering the Polish documents to the war trials in Nuremberg where he was permitted to witness one session of the proceedings. With a grant from the Polish Government, Adam was then accepted to study dentistry at Bristol University. During his nights at Wills Hall he would keep himself awake with damp towels wrapped around his neck, to have more hours in which to improve his English as well as complete his course work. He qualified with some of the highest marks.

Adam's first practice was in Calne and he then moved back to Bristol where he continued to work until retirement. He was cherished by his patients not only for his gentle treatment and professional competence but also for his caring attitude. He would often be a comfort to them, discussing personal issues with compassion and discretion.

After retirement Adam moved to Kent. He loved being near the sea and enjoyed the views of rolling countryside and picturesque towns and villages. He only became frail in his last couple of years and up until then enjoyed walking, shopping and good quality coffee with his wife Maria. He is survived by Maria and his two sons Robert and Marcus.

Marcus Lenko

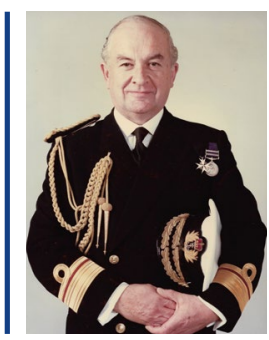

\section{Frank Mathias}

1927-2019

Surgeon Rear-Admiral (Dentist) Frank Mathias died aged 92. After two years at Sussex County Hospital, Brighton, 1952-53, Mathias was called up for National Service, but given the variety of challenging appointments available he soon decided to make the Navy his full career.

One of these challenges came in 1954-55 while serving in Hong Kong. Mathias volunteered to take dental aid in to the New Territories. Using a foot powered drill, dentistry was conducted in outlying villages, often in the open but sometimes in the luxury of a temple or schoolroom.
Another experience came in 1963, when the aircraft carrier Centaur heard that the Greek cruise ship Lakonia had caught fire off Morocco. When, after twelve hours steaming at 27 knots, Centaur arrived at the disaster, some fourteen ships were involved in search and rescue and had taken onboard 900 survivors. After 55 corpses were recovered from the sea, Mathias set to work on the flight deck to make a full dental record of each body. The corpses were landed at Gibraltar on Christmas Day. On the same deployment, Mathias assisted at operations on casualties of the Tanganyika mutiny.

Before he joined Centaur, he also qualified in anaesthetics, but during his first operation was alarmed to find that his patient was deteriorating, while the senior surgeon put down his instruments to stand in the corner of the operating theatre with his head bowed. Told that the surgeon was praying, Mathias told him in direct language to get back to the operation and he could do his praying once the patient had been saved.

Frank Russell Bentley Mathias was the youngest of nine children born to a family solicitor in Narberth, Pembrokeshire. He was educated at Narberth Grammar School, from where he won a place at Guy's Hospital.

Mathias was always great company. With a quick wit and sharp mind, every meeting with him was spontaneous and warm, littered with his fascinating reminiscences, astute observations and sage advice. He was the first naval dentist to be made an Officer Brother of the Order of St John of Jerusalem (1981) and as the Director of Naval Dental Services, he was HM the Queen's Honorary Dental Surgeon 1982-85.

He married Joy Daniels in 1954 who predeceased him in 2018, and he is survived by a daughter, and his son who became a submariner and a Rear Admiral.

Peter Hore 